\title{
Malignant Somatostatinoma
}

National Cancer Institute

\section{Source}

National Cancer Institute. Malignant Somatostatinoma. NCI Thesaurus. Code C65190.

A malignant neuroendocrine tumor arising from delta cells which produce somatostatin.

It displays vascular invasion and metastasizes to other anatomic sites. 